
ІННОВАЦІЙНІ СТРАТЕГІЇ ЯК ПЕРСПЕКТИВНИЙ НАПРЯМ ПЛАНУВАННЯ
ДІЯЛЬНОСТІ ГОТЕЛЬНИХ ТА РЕСТОРАННИХ ПІДПРИЄМСТВ УКРАЇНИ

\title{
INNOVATIVE STRATEGIES AS A PROSPECTIVE DIRECTION OF PLANNING ACTIVITIES OF HOTEL AND RESTAURANT ENTERPRISES OF UKRAINE
}

УДК 338.48

DOI: https://doi.org/10.32843/infrastruct59-10

Нещадим л.м.

к.е.н., доцент,

доцент кафредри технологій

і організації туризму

і готельно-ресторанної справи

Уманський педагогічний університет

імені Павла Тичини

Тимчук С.B.

к.е.н., доцент каредри туризму

та готельно-ресторанної справи

Уманський національний університет садівництва

Neshchadym Ljudmila

Pavlo Tychyna Uman State

Pedagogical University

Tymchuk Svetlana

Uman National University Gardening у статті проведено моніторинг та проаналізовано основні стратегії розвитку готельних та ресторанних підприємств, а також підвищення їх есрективності та конкурентоспроможності; удосконалено прочес організації та економічного планування діяльності підприємств готельно-ресторанної сфрери. Визначено, що підприємства готельно-ресторанного господарства України частково забезпечують необхідні якісні показники щодо наданих послуг, а це є причиною недостатнього рівня конкурентоспроможності послуг на внутрішньому ринку та в країнах Європи. Нагальною проблемою планування та організації діяльності підприємств готельно-ресторанного господарства є використання інноваційних стратегій та напрямів перспективного розвитку задля підвищення рівня конкурентоспроможності та якості наданих послуг. Це дасть змогу інтенсифрікувати інноваційні процеси в Україні у ссрері обслуговування. Інноваційні стратегії та перспективні напрями розвитку підприємств готельно-ресторанного господарства $є$ надзвичайно важливими в процесі управління готельними та ресторанними комплексами.

Ключові слова: планування, організація, стратегія, принципи стратегічного управління, ефрективність планування, готельне підприємство, ресторанне підприємство.

В статье проведен мониторинг и проанализированы основные стратегии развития гостиничных и ресторанных предприятий, а также повышение их эфрфективности и конкурентоспособности; усовершенствован процесс организации и экономического планирования деятельности предприятий гостинично-ресторанной ссреры. Определено, что предприятия гостинично-ресторанного хозяйства Украины частично обеспечивают необходимые качественные показатели по предоставляемым услугам, а это является причиной недостаточного уровня конкурентоспособности услуг на внутреннем рынке и в странах Европы. Насущной проблемой планирования и организации деятельности предприятий гостинично-ресторанного хозяйства является использование инновационных стратегий и направлений перспективного развития в целях повышения уровня конкурентоспособности и качества предоставляемых услуг. Это позволит интенсифицировать инновационные процессы в Украине в сфрере обслуживания. Инновационные стратегии и перспективные направления развития предприятий гостинично-ресторанного хозяйства являются чрезвычайно важными в процессе управления гостиничными и ресторанными комплексами.

Ключевые слова: планирование, организация, стратегия, принципы стратегического управления, эфрфрективность планирования, гостиничное предприятие, ресторанное предприятие.

The article monitors and analyzes the main strategies for the development of hotel and restaurant enterprises and, accordingly, increase their efficiency and competitiveness; the process of organization and economic planning of hotel and restaurant enterprises has been improved. It is investigated that the enterprises of hotel and restaurant industry of Ukraine partially provide the necessary quality indicators for the provided services, and this is the reason for the insufficient level of competitiveness of services in the domestic market and in European countries. An urgent problem of planning and organizing the activities of hotel and restaurant enterprises is the use of innovative strategies and areas of long-term development to increase the level of competitiveness and quality of services provided. This will intensify innovation processes in Ukraine in the field of services. Innovative strategies and promising areas of development of hotel and restaurant enterprises are extremely important in the management of hotel and restaurant complexes. Innovative strategies in the hotel and restaurant industry are cost-effective and feasible provided a high level of profitability, improving the service process, expanding the range of services, reducing costs, increasing competitiveness, improve and optimize the work of all hotel or restaurant services. The application of innovative strategies in the process of hotel and restaurant enterprises allows them to compete in the field of service. In conditions of fierce competition and rapidly changing market conditions, it is very important not only to focus on the internal state of affairs of the enterprise, but also to develop a long-term strategy. Economic activity requires constant innovation. All services offered by hotel and restaurant enterprises must be introduced in modern innovative ways. This is the basis for successful business, maintaining a consistently high level of competitiveness and improving the quality of service. The selection of the optimal innovation strategy for a hotel or restaurant company is carried out by its management based on the analysis of key factors that characterize its condition and the state of the product portfolio.

Key words: planning, organization, strategy, principles of strategic management, planning efficiency, hotel enterprise, restaurant enterprise.

Постановка проблеми. В сучасних умовах туристична галузь та ресторанне господарства $€$ невід'ємною частиною індустрій' гостинності. Готельно-ресторанна ссрера України в сучасних умовах динамічно розвивається та $є$ високо прибутковим сектором економіки.

Варто відзначити, що в Україні індустрія гостинності розвивається недостатньо швидко та ефрективно порівняно з європейським досвідом. Застосування прогресивних та інноваційних стратегій розвитку підприємств готельного та ресторанного господарства дасть змогу ефективно планувати їх діяльність, тому вибрана тематика дослідження є надзвичайно актуальною.

Аналіз останніх досліджень і публікацій. Дослідженням інноваційних стратегій у готельноресторанному господарстві займалося багато вітчизняних вчених, таких як Л.П. Артеменко, Л.Є. Довгань, Ю.В. Земліна, Ю.І. Клюс, О.І. Ковтун, О.С. Ліфіренко, О.П. Пархоменко, І.М. Поворознюк, Ю.В. Каракай. 
Проблемами розвитку готельних та ресторанних підприємств займались такі вітчизняні та зарубіжні вчені, як О.А. Воробйова, М.І. Долішній, І.М. Кирилюк, Л.М. Кузьменко, І.М. Поворознюк, В.Ф. Семенов, С.В. Тимчук, В.Г. Топольник, С.К. Харічков, Л.І. Нечаюк, Н.О. Телеш. Проте деякі питання стосовно застосування інноваційних стратегій недостатньо досліджені.

Постановка завдання. Метою дослідження $€$ моніторинг та аналіз інноваційних стратегій і напрямів перспективного розвитку готельних та ресторанних підприємств України.

Виклад основного матеріалу дослідження. В сучасних умовах глобалізації та інтелектуалізації всіх сорер діяльності інноваційні стратегії та технології у сфрері обслуговування є основою ефективної конкурентоспроможності.

Підприємства готельно-ресторанного господарства України частково забезпечують необхідні якісні показники щодо наданих послуг. Це $є$ базовим чинником недостатнього рівня конкурентоспроможності послуг на внутрішньому ринку та в країнах Європи. Нагальною проблемою планування та організації діяльності підприємств готельно-ресторанного господарства $€$ використання інноваційних стратегій та напрямів перспективного розвитку задля підвищення рівня конкурентоспроможності та якості наданих послуг. Це дасть змогу інтенсиорікувати інноваційні процеси в Україні у сорері обслуговування.

Інноваційні стратегії та перспективні напрями розвитку підприємств готельно-ресторанного гос- подарства $€$ надзвичайно важливими в процесі управління готельними та ресторанними комплексами.

Інноваційний процес являє собою сукупність процедур і засобів, за допомогою яких наукове відкриття, ідея перетворюються на соціальне, у тому числі освітнє, нововведення [2; 4]. Таким чином, діяльність, що забезпечує перетворення ідей на нововведення, а також фрормує систему керування цим процесом, є інноваційною діяльністю [4]. Нововведення за такого підходу розуміється як результат інновації, а інноваційний процес містить принаймні три етапи, такі як генерування ідеї (у певному випадку - наукове відкриття), розроблення ідеї в прикладному аспекті, реалізація нововведення на практиці [4; 7].

В сучасних умовах розвитку індустрії гостинності одним із важливих чинників ефективності їх діяльності $€$ постійні інновації в процесі та збалансована стратегія розвитку.

Інноваційні стратегії в готельно-ресторанному господарстві $€$ економічно ефективними та доцільними за умови забезпечення високого рівня прибутковості, вдосконалення процесу обслуговування, розширення асортименту послуг, зниження витрат, підвищення рівня конкурентоспроможності, а також покращують та оптимізують роботу всіх служб готелю чи ресторану.

Застосування інноваційних стратегій у процесі роботи готельно-ресторанних підприємств дає їм змогу якісно конкурувати у сфері обслуговування. В умовах твердої конкуренції та швидкозмінних

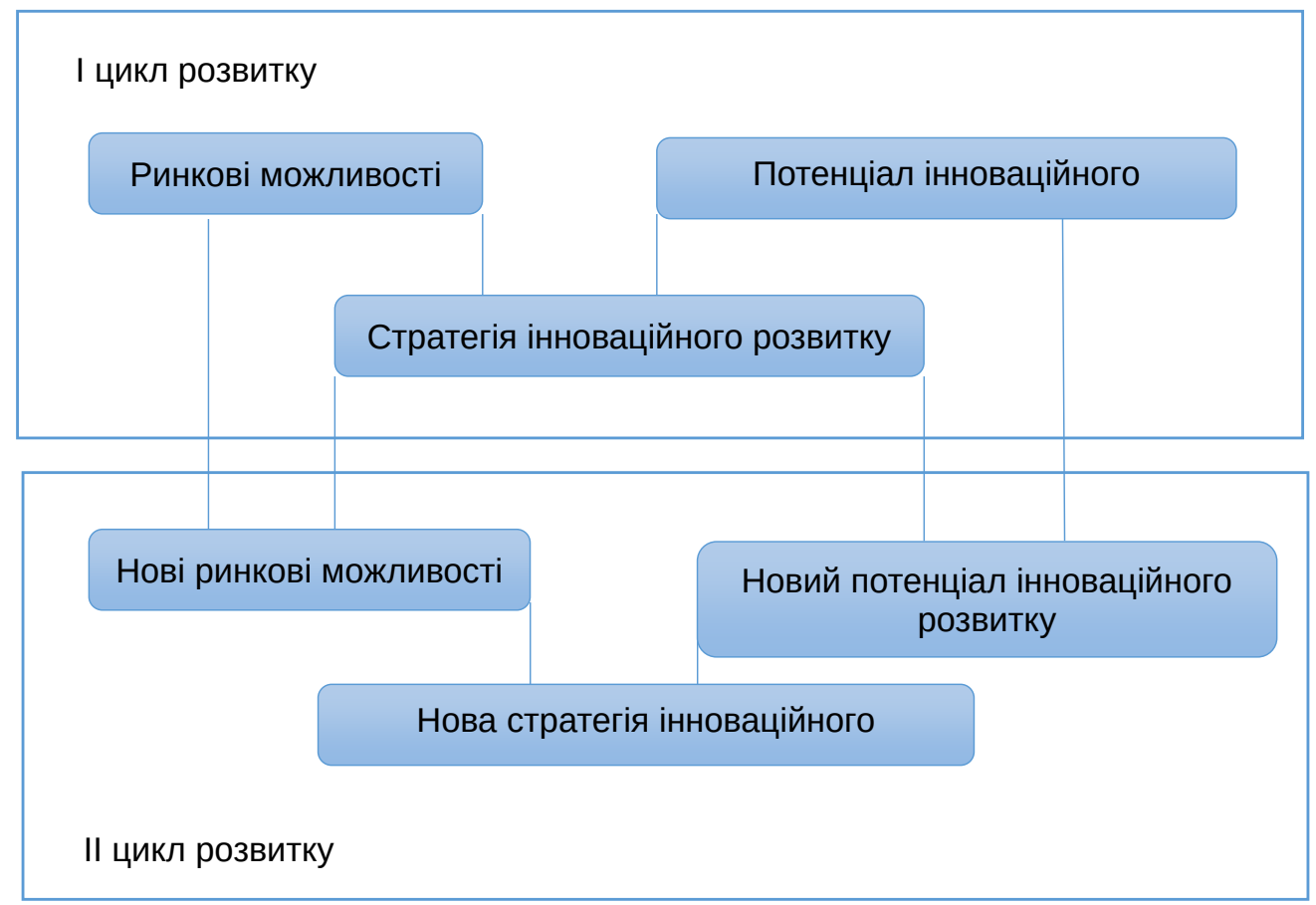

Рис. 1. Схема розвитку зростання інноваційних стратегічних можливостей готельно-ресторанних підприємств

Джерело: сформовано авторами на основі джерела [10] 
ситуацій на ринку дуже важливо не тільки зосереджувати увагу на внутрішньому стані речей підприємства, але й виробляти довгострокову стратегію [5].

Економічна діяльність вимагає постійної інноваційності. Всі послуги, які пропонуються готельноресторанними підприємствами, повинні запроваджуватися сучасними інноваційними способами. Це $є$ основою для успішного ведення підприємницької діяльності, підтримання постійно високого рівня конкурентоспроможності та підвищення якості обслуговування.

Підбір оптимальної інноваційної стратегії для готельного чи ресторанного підприємства здійснює його керівництво на основі аналізу ключових чинників, що характеризують його стан і стан портореля продукції [4].

Інноваційна стратегія - головна умова досягнення цілей підприємств сорери обслуговування й характеризується новизною, передусім для підприємства [2, с. 54]. Застосування в практичній діяльності інноваційних стратегій дасть можливість готельним та ресторанним підприємствам вийти на вищий рівень розвитку та забезпечить досягнення таких цілей:
- еорективність існування на ринку, високий рівень конкурентоспроможності та просування готельно-ресторанних підприємств;

- відповідність усім сучасним вимогам та потребам споживачів готельно-ресторанних послуг;

- покращення іміджу підприємства та привабливості його послуг;

- створення привабливого інвестиційного клімату в країні для залучення венчурних інвестицій;

- фрормування бази для залучення міжнародних туристичних операторів на вітчизняному ринку.

Готельне чи ресторанне підприємство, що вибрало інноваційну стратегію для подальшого розвитку та підвищення ефективності діяльності, обов'язково має покращувати матеріально-технічне забезпечення, оптимізувати роботу всіх служб та підрозділів, вдосконалювати виробничу базу та систему надання послуг з огляду на потреби та вимоги споживачів. Паралельно 3 цим у підприємствах готельно-ресторанного господарства вдосконалюються система управління та організаційна система, працівники підвищують кваліфікаційний рівень, залучаються досвідчені

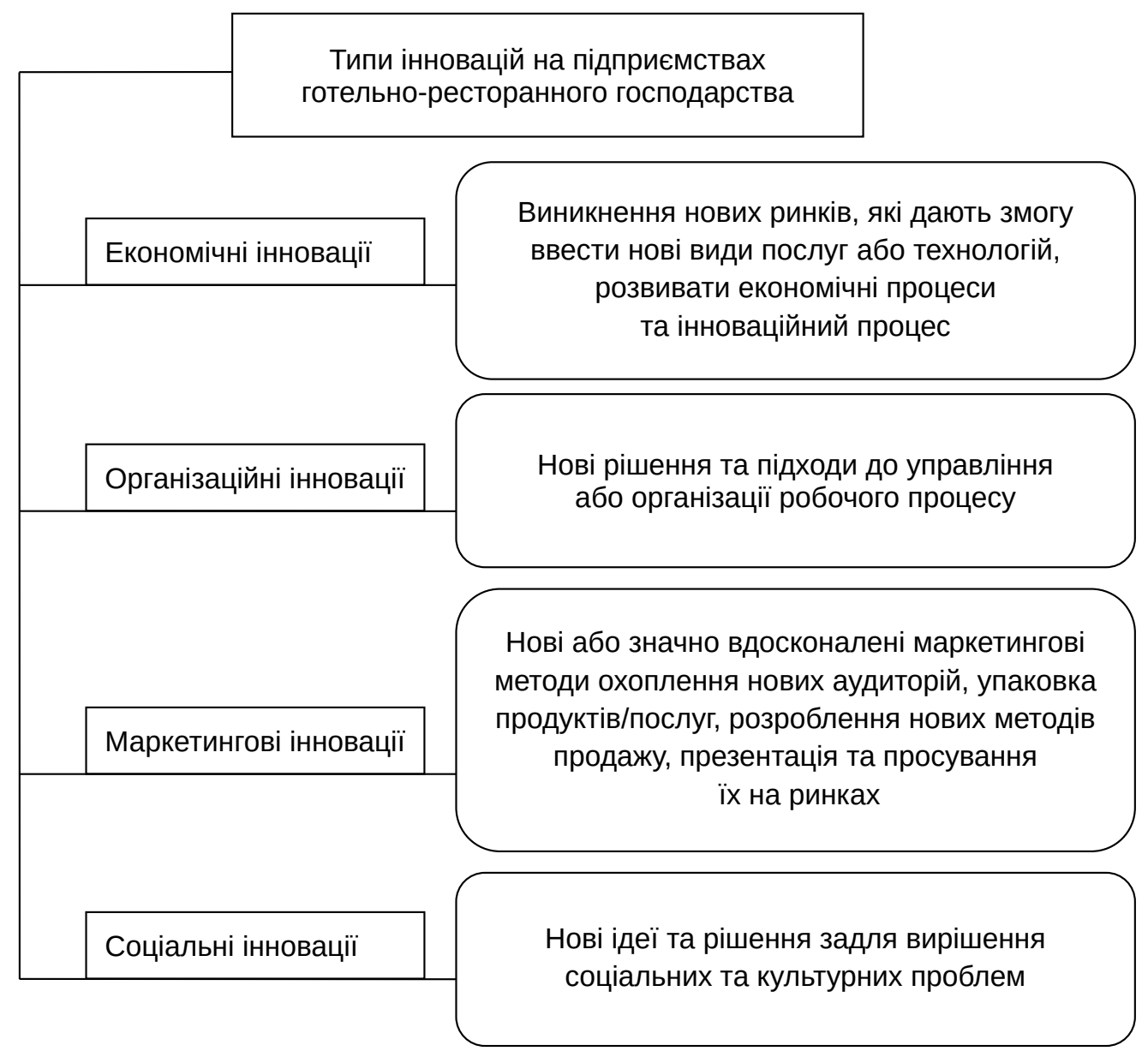

Рис. 2. Основні типи інновацій у підприємствах сфери обслуговування 
управлінці та керівники. Ці зміни прямо впливають на підвищення іміджу готельно-ресторанного підприємства на ринку та дають змогу реалізувати нові ринкові можливості, проникнути в нові ссрери діяльності, які раніше для нього були недоступними [3; 5; 7]. Кожна наступна ефективно впроваджена інноваційна стратегія розширює можливості готельно-ресторанних підприємств, хоча, звичайно, є певна межа розвитку (наприклад, стратегія може бути обмежена масштабами діяльності) [5].

Реалізація такого підходу до діяльності готельно-ресторанних підприємств забезпечує розвиток зростання їх стратегічних можливостей. Схема інноваційного розвитку, яку пропонує С.М. Ілляшенко [4], зображена на рис. 1.

Швидкий економічний розвиток диктує постійне оновлення та вдосконалення стратегій готельноресторанних підприємств. Вибір інноваційних стратегій залишається за керівництвом підприємства.

Сьогодні виділяють такі основні типи інновацій у підприємствах сорери обслуговування (рис. 2) [6].

Якщо характеризувати саме інноваційні стратегії підприємств готельно-ресторанного господарства, то в цій сорері вирізняють такі їх типи [4-6]:

- стратегія наступу;

- стратегія захисту;

- імітаційна стратегія;

- залежна стратегія;

- традиційна стратегія;

- стратегія «за нагодою», або стратегія «ніші».

Висновки з проведеного дослідження. Отже, інноваційний стратегічний розвиток готельноресторанних підприємств вимагає наявності інноваційної складової частини та бажання вдосконалювати процес планування діяльності. Запровадження інноваційних стратегій забезпечить підприємства сорери обслуговування конкурентними перевагами, а також дасть можливість задовольняти потреби споживачів. Проте вибрані інноваційні стратегії розвитку повинні обов'язково відповідати загальній стратегії підприємств готельно-ресторанного господарства.

\section{БІБЛІОГРАФІЧНИЙ СПИСОК:}

1. Інвестиційно-інноваційна діяльність: теорія, практика, досвід : монографія / М.П. Денисенко, Л.І. Михайлова, І.М. Грищенко, А.П. Гречан та ін. Суми : Університетська книга, 2008. 1050 с.

2. Яхтер А.М. Підвищення конкурентоспроможності підприємств ресторанного господарства за рахунок упровадження інноваційної діяльності. Збірник наукових праць Черкаського державного технологічного університету. Серія «Економічні науки». 2015. Вип. 39 (1). С. 132-137.

3. Balmer J.M. The shared management and ownership of corporate brands: the case of Hilton of general management. Oxford. 2009. Vol. 34. No. 4. P. 15-37.
4. Галасюк К.А. Аналіз існуючих методик оцінки інноваційного потенціалу підприємств сфрери послуг. Науковий вісник МНУ імені В.О. Сухомлинського. 2015. C. 98-102.

5. Developments and challenges in the hospitality and tourism sector: Issues paper for discussion at the global dialogue forum for the hotels, catering, tourism sector. Intern, labour organization. Sectoral activities programme. Geneva : ILO, Nov. 2013.

6. UNWTO. International tourism to continue robust growth in 2014. Press release. No. 13006. Madrid, Jan. 2014. URL: http://media.unwto.org/en/pressrelease/2014-01/international-tourism-continue-robustgrowth-2013.

7. Аналіз динаміки та головні тенденції розвитку туризму. Офріційний сайт Державної служби туризму і курортів України. URL: www.tourism.gov.ua/ CN.17/2014/PC21.

8. Пресс-релиз Hogg Robinson Group, январь 2013. URL: http://www.hrgworldwide.com/ru-ru/Pages/ default.aspx?ru.

9. Щетинина К.И. Инновации в гостиничном бизнесе: международный и российский опыт. Вестник МГИМО. 2013. Вып. 4 (31). URL: http://ehd.mgimo.ru/ IORManagerMgimo/file?id=BBBD7B5A-6841-6BC7 A88.

10. Travel \& Tourism Competitiveness Report 2014. World Economic Forum: URL: http://www.weforum.org/ docs/WEFGCRTravelTourismReport2014.pdf-E/CN.17/ 2014/PC21.

\section{REFERENCES:}

1. DenysenkoM.P.,MykhailovaL.I.,Ghryshhenkol.M., Ghrechan A.P. (2008) Investytsiino-innovatsiina diialnist: teoriia, praktyka, dosvid [Investment and innovation activity: theory]. Sumy: Universytetsjka knygha. (in Ukrainian)

2. Yakhter A.M. (2015) Pidvyshchennia konkurentospromozhnosti pidpryiemstv restorannoho hospodarstva za rakhunok uprovadzhennia innovatsiinoi diialnosti [Increasing the competitiveness of restaurants in the enterprise by introducing innovative activities]. Zbirnyk naukovykh prats Cherkaskoho derzhavnoho tekhnolohichnoho universytetu, Seriia: Ekonomichni nauky, vol. 39 (1), pp. 132-137.

3. Balmer J.M.T., Thomson I. (2009) The shared management and ownership of corporate brands: The case of Hilton. Journal of General Management, vol. 34, no. 4, pp. 15-37.

4. Halasiuk K.A. (2015) Analiz isnuiuchykh metodyk otsinky innovatsiinoho potentsialu pidpryiemstv sfery posluh [An analysis of existing methods for assessing the innovation potential of service enterprises]. Naukovyi visnyk imeni V.O. Sukhomlynsokoho, no. 1, pp. 98-102.

5. Developments and challenges in the hospitality and tourism sector. Issues paper for discussion at the Global Dialogue Forum for the Hotels, Catering, Tourism Sector. International Labour Organization. Sectoral Activities Programme. Geneva, ILO Publ. Nov. 2013. 102 p. Available at: http://www.ilo.org/wcmsp5/groups/ public/eddialogue/sector/documents/meetingdocument/ wcms_162202.pdf. 
6. UNWTO. International tourism to continue robust growth in 2014. World Tourism Organization UNWTO. Press Release, January 28, 2014, no. PR13006. Available at: http://media.unwto.org/en/ press-release/2014-01-28/international-tourism-continue-robust-growth-2013.

7. Analysis of the dynamics main trends and development of tourism. The official website of the State Tourism and Resorts of Ukraine. Available at: www.tourism.gov.ua.
8. Hogg Robinson Group Press Release, January 31, 2013. Available at: http://www.hrgworldside.com.

9. Shchetinina K.I. (2013) Innovations in the hotel business: international and Russian experience. Available at: http://ehd.mgimo.ru//ORManagerMgimo/file?ld= BBBD7B5A-6841-6BC7A880-909D10EC5558.

10. Travel \& Tourism Competitiveness Report 2014. World Economic Forum. Available at: http://www.weforum.org/docs/WEFGCRTravelTourismReport 2014.pdf. 